\title{
PENGARUH EKOWISATA BERBASIS MASYARAKAT TERHADAP PERUBAHAN KONDISI EKOLOGI, SOSIAL DAN EKONOMI DI KAMPUNG BATUSUHUNAN, SUKABUMI
}

\author{
Community Based Ecotourism influence the condition of Ecology, Social, and Economic \\ Batusuhunan village, Sukabumi
}

\author{
Emma Hijriati*) dan Rina Mardiana \\ Departemen Sains Komunikasi dan Pengembangan Masyarakat, Fakultas Ekologi Manusia, IPB \\ *)Email : hijriatiemma@gmail.com
}

\begin{abstract}
Ecotourism is responsible travel journey towards environmental sustainability and well being of local communities. Active role in managing ecotourism potential is important because people have the knowledge of nature and culture potential sale value as ecotourism attraction. The development of community managed ecotourism affects the ecological, social, and economic communities. The purpose of this study was to analyze the influence of community based ecotourism in village Batusuhunan to changing ecological, social, and economic community. The results showed that the presence of community based ecotourism Batusuhunan give change for the community especially in the ecological and social aspects. On ecological aspect, the population has had the awareness to protect the environment by disposing of waste in place and environmentally friendly lifestyle. In the social aspect, ecotourism increase cooperation of community especially in the field ecotourism. Social activities in the community often held in line with the development of ecotourism. On the economic, employment opportunities derived from ecotourism sector could be extra income for the family. However, changes in the standard of living can not be perceived by the Batusuhunan community because ecotourism development has just started and has been running for about 3 years.
\end{abstract}

Keywords: community Based Ecotourism, ecological, economic, social

\begin{abstract}
ABSTRAK
Ekowisata adalah perjalanan wisata yang bertanggung jawab terhadap kelestarian lingkungan dan kesejahteraan masyarakat setempat. Peran aktif dalam mengelola potensi ekowisata ini penting karena pengetahuan alam dan potensi budaya memiliki nilai jual sebagai daya tarik ekowisata. Perkembangan ekowisata mempengaruhi masyarakat pada aspek ekologi, sosial, dan ekonomi. Tujuan dari penelitian ini adalah untuk menganalisis perubahan kondisi ekologi, sosial, dan ekonomi di Kampung Batusuhunan setelah adanya ekowisata berbasis masyarakat. Hasil penelitian menunjukkan bahwa kehadiran ekowisata berbasis masyarakat Batusuhunan memberikan perubahan bagi masyarakat terutama dalam aspek ekologi dan sosial. Pada aspek ekologi, penduduk telah memiliki kesadaran untuk melindungi lingkungan dengan membuang sampah pada tempatnya dan mulai menerapkan gaya hidup ramah lingkungan. Dalam aspek sosial, terjadi peningkatan kerjasama masyarakat terutama di bidang ekowisata. Kegiatan sosial di masyarakat sering diadakan sejalan dengan perkembangan ekowisata. Pada ekonomi, kesempatan kerja yang berasal dari sektor ekowisata bisa menjadi penghasilan tambahan bagi keluarga. Namun, perubahan dalam standar hidup tidak dapat dirasakan oleh masyarakat Batusuhunan karena pengembangan ekowisata baru saja dimulai dan baru berjalan selama sekitar 3 tahun.
\end{abstract}

Kata kunci: ekologi, ekonomi, ekowisata berbasis masyarakat, sosial

\section{PENDAHULUAN}

Indonesia memiliki potensi keindahan alam dan kekayaan budaya yang bernilai tinggi dalam pasar industri ekowisata. Potensi alam tersebut dapat berupa sumberdaya alam hayati dan ekosistemnya, keanekaragaman flora, fauna dan gejala alam dengan keindahan pemandangan yang masih alami. Untuk kebudayaan, Indonesia memiliki sistem religi, kesenian, bahasa daerah, ritus kebudayaan, pengetahuan, dan organisasi sosial. Berdasarkan laporan World Travel Tourism Council (WTTC) Tahun 2000 pertumbuhan ekowisata rata-rata sebesar 10 persen per tahun. Angka tersebut lebih tinggi dibandingkan pertumbuhan rata-rata per tahun untuk pariwisata pada umumnya yaitu sebesar 4.6 persen per tahun. Sebagai bentuk wisata, ekowisata mempunyai kekhususan tersendiri yaitu mengedepankan konservasi lingkungan, pendidikan lingkungan, kesejahteraan penduduk lokal, dan menghargai budaya lokal. Sehingga ekowisata banyak diminati wisatawan, 
hal ini karena adanya pergeseran paradigma kepariwisataan internasional dari bentuk pariwisata masal (mass tourism) ke wisata minat khusus yaitu ekowisata.

Terbitnya Peraturan Menteri Dalam Negeri Nomor 33 Tahun 20091 tentang Pedoman Pengembangan Ekowisata di Daerah, telah mendorong Pemerintah Daerah untuk mengembangkan ekowisata yang belakangan ini telah menjadi trend dalam kegiatan kepariwisataan di Indonesia. Secara garis besar, peraturan ini menjelaskan bahwa ekowisata merupakan potensi sumberdaya alam, lingkungan, serta keunikan alam dan budaya yang dapat menjadi salah satu sektor unggulan daerah yang belum dikembangkan secara optimal. Dengan demikian, dalam rangka pengembangan ekowisata di daerah secara optimal perlu strategi perencanaan, pemanfaatan, pengendalian, penguatan kelembagaan, serta pemberdayaan masyarakat dengan memperhatikan kaidah-kaidah sosial, ekonomi, ekologi, dan melibatkan pemangku kepentingan dalam mengelola potensi ekowisata.

\section{Perumusan Masalah}

Pengembangan ekowisata tentu akan memberikan pengaruh terhadap kehidupan masyarakat, sehingga terjadi perubahan dalam aspek ekologi sosial dan ekonomi masyarakat setempat. Perubahan tersebut ada yang bersifat positif dan ada yang negatif. Dengan demikian, agar nantinya pengelolaan ekowisata berbasis masyarakat di Curug Cigangsa lebih memberikan kontribusi secara signifikan terhadap ekologi, sosial dan ekonomi masyarakat setempat, maka sejak awal perlu dilakukan penelitian yang mendalam mengenai pengaruh ekowisata terhadap ekologi, sosial, dan ekonomi di Curug Cigangsa. Terkait dengan kondisi tersebut, rumusan masalah yang diangkat dalam penelitian ini adalah sebagai berikut:

1. Bagaimana perubahan kondisi ekologi di Kampung Batusuhunan setelah adanya ekowisata berbasis masyarakat?

2. Bagaimanakah perubahan kondisi sosial di Kampung Batusuhunan setelah adanya ekowisata berbasis masyarakat?

3. Bagaimanakah perubahan kondisi ekonomi di Kampung Batusuhunan setelah adanya ekowisata berbasis masyarakat?

\section{Tujuan Penelitian}

Tujuan penelitian dirumuskan sebagai berikut:

1. Menganalisis perubahan kondisi ekologi di Kampung Batusuhunan setelah adanya ekowisata berbasis masyarakat.

2. Menganalisis perubahan kondisi sosial di Kampung Batusuhunan setelah adanya ekowisata berbasis masyarakat.

3. Menganalisis perubahan kondisi ekonomi di Kampung Batusuhunan setelah adanya ekowisata berbasis masyarakat

\section{Kegunaan Penelitian}

Penelitian ini memiliki kegunaan sebagai berikut:

1. Bagi akademisi, penelitian ini diharapkan dapat menjadi bahan referensi dan kajian untuk penelitian selanjutnya terkait perubahan ekologi, sosial, dan ekonomi di kawasan ekowisata.

2. Bagi pemerintah, penelitian ini diharapkan dapat menjadi bahan pertimbangan dalam penetapan kebijakan pengembangan ekowisata kedepan.

3. Bagi masyarakat, dapat memberikan pemahaman dan wawasan dalam mengoptimalkan pengelolaan ekowisata berbasis masyarakat.

\section{PENDEKATAN TEORITIS}

\section{Pariwisata, Ekowisata, dan Prinsip Ekowisata}

Pariwisata adalah aktivitas perjalanan yang dilakukan untuk sementara waktu dari tempat tinggal semula ke daerah tujuan dengan alasan bukan untuk menetap atau mencari nafkah melainkan hanya untuk bersenang-senang, memenuhi rasa ingin tahu dan menghabiskan waktu senggang atau waktu libur (Zalukhu, 2009 seperti dikutip Saputro, 2011).

Berbeda dengan pariwisata, ekowisata didefinisikan The International Ecotourism Society (TIES) (2000) seperti dikutip Damanik dan Weber (2006) sebagai perjalanan wisata alam yang bertanggung jawab terhadap lingkungan dan meningkatkan kesejahteraan masyarakat lokal.

\section{Pengembangan Ekowisata Berbasis Mayarakat}

Ekowisata berbasis masyarakat merupakan usaha ekowisata yang menitikberatkan peran aktif masyarakat. Hal tersebut didasarkan kepada kenyataan bahwa masyarakat memiliki pengetahuan tentang alam serta budaya yang menjadi potensi dan nilai jual sebagai daya tarik wisata, sehingga pelibatan masyarakat menjadi mutlak. Pola ekowisata berbasis masyarakat mengakui hak masyarakat lokal dalam mengelola kegiatan wisata di kawasan yang mereka miliki secara adat ataupun sebagai pengelola. Dengan adanya pola ekowisata berbasis masyarakat bukan berarti masyarakat akan menjalankan usaha ekowisata sendiri.

Berdasarkan Peraturan Menteri Dalam Negeri Nomor 33 Tahun 2009 bahwa prinsip pengembangan ekowisata meliputi: (1) kesesuaian antara jenis dan karakteristik ekowisata; (2) konservasi, yaitu melindungi, mengawetkan, dan memanfaatkan secara lestari sumberdaya alam yang digunakan untuk ekowisata; (3) ekonomis, yaitu memberikan manfaat untuk masyarakat setempat dan menjadi penggerak pembangunan ekonomi di wilayahnya serta memastikan usaha ekowisata dapat berkelanjutan; (4) edukasi, yaitu mengandung unsur pendidikan untuk mengubah persepsi seseorang agar memiliki kepedulian, tanggung jawab, dan komitmen terhadap pelestarian lingkungan dan budaya; (5) memberikan kepuasan dan pengalaman kepada pengunjung; (6) partisipasi masyarakat, yaitu peran serta masyarakat dalam kegiatan perencanaan, pemanfaatan, dan pengendalian ekowisata dengan menghormati nilai- nilai sosial-budaya dan keagamaan masyarakat di sekitar kawasan; dan (7) menampung kearifan lokal.

\section{Dampak Ekowisata}

Dampak adalah suatu perubahan yang terjadi sebagai akibat suatu aktivitas (Soemarwoto, 1989). Ekowisata merupakan salah satu sektor penting dalam pembangunan. Pengelolaan ekowisata yang baik akan menghasilkan beberapa keuntungan dalam berbagai aspek. Akan tetapi, apabila tidak dikelola 
dengan benar, maka ekowisata dapat berpotensi menimbulkan masalah atau dampak negatif. Berdasarkan kacamata ekonomi makro, ekowisata memberikan beberapa dampak positif (Yoeti, 2008), yaitu :

1. Menciptakan kesempatan berusaha;

2. Menciptakan kesempatan kerja;

3. Meningkatkan pendapatan sekaligus mempercepat pemerataan pendapatan masyarakat, sebagai akibat multiplier effect yang terjadi dari pengeluaran wisatawan yang relatif cukup besar;

4. Meningkatkan penerimaan pajak pemerintah dan retribusi daerah;

5. Meningkatkan pendapatan nasional atau Gross Domestic Bruto (GDB);

6. Mendorong peningkatan investasi dari sektor industri pariwisata dan sektor ekonomi lainnya;

7. Memperkuat neraca pembayaran. Bila neraca pembayaran mengalami surplus, dengan sendirinya akan memperkuat neraca pembayaran Indonesia, dan sebaliknya.

Pengembangan ekowisata tidak saja memberikan dampak positif, tetapi juga dapat memberikan beberapa dampak negatif, antara lain (Yoeti, 2008):

1. Sumber-sumber hayati menjadi rusak, yang menyebabkan Indonesia akan kehilangan daya tariknya untuk jangka panjang;

2. Pembuangan sampah sembarangan yang selain menyebabkan bau tidak sedap, juga dapat membuat tanaman di sekitarnya mati;

3. Sering terjadi komersialisasi seni-budaya; dan

4. Terjadi demonstration effect, kepribadian anak-anak muda rusak. Cara berpakaian anak-anak sudah mendunia berkaos oblong dan bercelana kedodoran.

\section{Pengaruh terhadap Ekologi}

Pengembangan ekowisata harus benar-benar dilakukan denagn penuh kehati-hatian dan pengelolaan yang cermat, tidak terjebak atau tergiur pada keuntungan ekonomi jangka pendek, tetapi harus berpedoman pada pengembangan berkelanjutan. Artinya, generasi kini dapat memetik manfaatnya, namun tanpa melupakan bahwa generasi berikutnya pun memiliki hak mendapat manfaat SDA yang sama (Warpani, 2007). Oleh karena itu, kebijakan dalam kaitan dengan ekowisata dilandasi oleh dimensi ekologi yaitu (Damanik dan Weber, 2006):

1. Penentuan dan konsistensi pada daya dukung lingkungan.

2. Pengelolaan limbah dan pengurangan penggunaan bahan baku hemat energi

3. Prioritas pengembangan produk dan layanan jasa berbasis lingkungan.

4. Peningkatan kesadaran lingkungan dengan kebutuhan konservasi.

Pengembangan ekowisata dapat mendatangkan dampak positif berupa meningkatnya upaya reservasi sumberdaya alam, pembangunan taman nasional, perlindungan pantai, dan taman laut. Namun di lain pihak, pengelolaan kegiatan ekowisata yang kurang tepat dapat menimbulkan dampak negatif berupa polusi, kerusakan lingkungan fisik, pemanfaatan berlebihan, pembangunan fasilitas tanpa memperhatikan kondisi lingkungan, dan kerusakan hutan mangrove (Tuwo, 2011).

\section{Pengaruh terhadap Sosial Budaya}

Ekowisata sebagai industri pariwisata merupakan bagian dari cultural industry yang melibatkan seluruh masyarakat. Meskipun hanya sebagian masyarakat yang terlibat, namun pengaruh sosial lebih luas seperti terjadinya ketimpangan/ kesenjangan sosial dalam masyarakat. Pengaruh pariwisata terhadap masyarakat termasuk terjadinya perubahan proses sosial masyarakat yang di dalamnya terdapat kerjasama dan persaingan antara pelaku pariwisata. Proses sosial adalah hubungan timbal balik antar individu, individu dengan kelompok, dan antar kelompok, berdasarkan potensi atau kekuatan masing-masing (Abdulsyani, 1994).

Proses sosial merupakan aspek dinamis dari kehidupan masyarakat dimana terdapat proses hubungan antar manusia berupa interaksi sosial yang terjadi dalam kehidupan manusia secara terus-menerus. Terbentuknya interaksi sosial apabila terjadi kontak sosial dan komunikasi sosial. Proses sosial dapat terjadi dalam berbagai bentuk yaitu, kerjasama, persaingan, pertikaian/pertentangan, dan akomodasi (Tafalas, 2010).

\section{Pengaruh terhadap Ekonomi}

Menurut Sedarmayanti (2005) kegiatan ekowisata yang banyak menarik minat wisatawan telah memberikan sumbangan devisa untuk negara dan juga telah membuka kesempatan lapangan pekerjaan bagi masyarakat sekitar. Masyarakat tidak saja mendapatkan pekerjaan dan peningkatan pendapatan, tetapi juga dapat menciptakan suatu lapangan pekerjaan baru yang menunjang kegiatan pariwisata.

Taraf hidup dikutip dari Data BPS tahun 2005 dalam Rahman (2009) adalah variabel kemiskinan yaitu luas lantai bangunaan tempat tinggal, jenis lantai bangunan tempat tinggal, fasilitas tempat buang air besar, sumber penerangan rumah tangga, sumber air minum, bahan bakar untuk memasak, konsumsi daging/ayam/susu/perminggu, pembeliaan pakaian baru setiap anggota rumah tangga setiap tahun, frekuensi makan dalam sehari, kemampuan membayar untuk berobat ke puskesmas atau dokter, lapangan pekerjaan kepala rumahtangga, pendidikan tertinggi kepala rumah tangga dan kepemilikan asset/harta bergerak maupun tidak bergerak. Taraf hidup adalah tingkat kemampuan untuk memenuhi kebutuhan hidupnya.

\section{Kerangka Pemikiran}

Adanya potensi ekowisata berupa Curug Cigangsa di Kampung Batusuhunan, Kelurahan Surade, Sukabumi menjadikan kawasan ini sebagai salah satu lokasi pengembangan ekowisata di Sukabumi. Dalam pengembangannya, ekowisata Curug Cigangsa menerapkan konsep ekowisata berbasis masyarakat mengingat masyarakat memiliki peran penting dalam kegiatan ekowisata. Ekowisata berbasis masyarakat merupakan usaha ekowisata yang menitikberatkan peran aktif komunitas. Hal tersebut didasarkan kepada kenyataan bahwa masyarakat memiliki pengetahuan tentang alam serta budaya yang menjadi potensi dan nilai jual sebagai daya tarik wisata, sehingga pelibatan masyarakat menjadi mutlak.

Penelitian ini akan mengkaji perubahan kondisi ekologi dan 
sosial ekonomi masyarakat yang terjadi sebelum dan setelah adanya ekowisata berbasis masyarakat. Perubahan dari aspek ekonomi, dapat dilihat dari variabel taraf hidup masyarakat. Sedangkan dari aspek sosial, dilihat dari variabel tingkat kerjasama antar masyarakat. Serta pada aspek ekologi yaitu tigkat keterlibatan masyarakat dalam menjaga kelestarian lingkungan. Untuk lebih jelasnya, dapat dilihat pada Gambar 1.

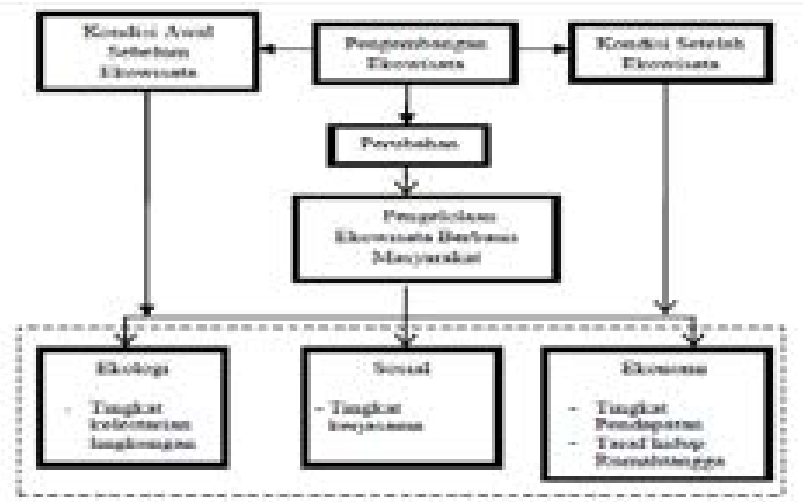

Gambar 1. Kerangka Pemikiran

\section{Hipotesis Penelitian}

1. Ho: Tidak terdapat beda nyata antara kondisi ekologi sebelum dan setelah adanya ekowisata berbasis masyarakat di Kampung Batusuhunan.

H1: Terdapat beda nyata antara kondisi ekologi sebelum dan setelah adanya ekowisata berbasis masyarakat di Kampung Batusuhunan.

2. Ho: Tidak terdapat beda nyata antara kondisi sosial sebelum dan setelah adanya ekowisata berbasis masyarakat di Kampung Batusuhunan.

H1: Terdapat beda nyata antara kondisi sosial sebelum dan setelah adanya ekowisata berbasis masyarakat di Kampung Batusuhunan.

3. Ho: Tidak terdapat beda nyata antara kondisi ekonomi sebelum dan setelah adanya ekowisata berbasis masyarakat di Kampung Batusuhunan.

H1: Terdapat beda nyata antara kondisi ekonomi sebelum dan setelah adanya ekowisata berbasis masyarakat di Kampung Batusuhunan.

\section{METODE}

\section{Lokasi dan Waktu Penelitian}

Penelitian ini dilaksanakan di lokasi tempat dikembangkannya kawasan ekowisata Curug Cigangsa, yaitu di Kampung Batusuhunan, Kelurahan Surade, Kabupaten Sukabumi, Jawa Barat. Penentuan lokasi penelitian dilakukan secara sengaja (purposive) berdasarkan hasil pengamatan peneliti sebelumnya terhadap lokasi melalui internet, studi literatur, dan survei penelitian. Lokasi ini dipilih dengan pertimbangan bahwa Kampung Batusuhunan memiliki potensi ekowisata berupa Curug Cigangsa yang dikelola berbasis masyarakat. Kampung Batusuhunan merupakan kampung yang lokasinya paling dekat dengan Curug Cigangsa, sehingga kegiatan ekowisata yang dilakukan di Curug Cigangsa akan memberikan pengaruh langsung terhadap masyarakat Kampung Batusuhunan. Selain itu, Kampung Batusuhunan merupakan kawasan yang menjadi prioritas pertama dalam pembangunan wilayah Kelurahan Surade karena selama ini wilayah Kampung Batusuhunan kurang berkembang dibandingkan dengan kampung-kampung di Kelurahan Surade lainnya. Penelitian lapangan dilakukan pada bulan April sampai dengan Mei 2013.

\section{Teknik Pengambilan Sampel}

Populasi sasaran dari penelitian ini adalah masyarakat Kampung Batusuhunan, Kelurahan Surade, Kecamatan Surade, Kabupaten Sukabumi. Populasi adalah jumlah keseluruhan dari unit analisa yang ciri- cirinya diduga. Unit analisis yang diteliti adalah rumahtangga. Populasi dalam penelitian ini adalah rumahtangga pemilik usaha di bidang ekowisata, bekerja di industri ekowisata, maupun pengelola ekowisata yang berada di Kampung Batusuhunan RW 08 yang terdiri atas 5 RT yaitu, RT 11, 12, 14, 16, dan 17. Unit sasaran dalam penelitian ini adalah suami/istri/anggota rumahtangga lainnya yang dapat memberikan data yang relevan mengenai masalah penelitian.

Responden didefinisikan sebagai pihak yang memberi keterangan tentang diri sendiri dan kegiatan yang dilaksanakannya. Penelitian ini menggunakan metode sensus, sehingga semua anggota populasi dijadikan responden dalam penelitian ini. Penentuan responden tersebut berdasarkan alasan bahwa pemilik usaha, pekerja, dan pengelola di bidang ekowisata merupakan masyarakat yang terlibat dalam penyelenggaraan ekowisata berbasis masyarakat sehingga dapat memberikan data yang relevan mengenai perubahan kondisi ekologi, sosial, dan ekonomi sebelum dan setelah adanya ekowisata. Jumlah responden dengan metode sensus ini berjumlah 34 orang yang terlibat langsung dalam kegiatan usaha ekowisata di Kampung Batusuhunan.

Pendekatan kualitatif diperoleh melalui wawancara mendalam kepada informan. Informan dipilih dengan menggunakan metode snowball. Informan merupakan pihak yang memberikan keterangan tentang diri sendiri, pihak lain dan lingkungannya, dalam penelitian ini khususnya mengenai pengelolaan ekowisata kampung batusuhunan, profil desa, serta perubahan ekologi dan sosial ekonomi masyarakat dengan adanya pengembangan ekowisata di Kampung Batusuhunan.

\section{Teknik Pengumpulan Data}

Data yang digunakan dalam penelitian ini adalah data primer dan data sekunder. Data primer diperoleh dari kuesioner dan wawancara mendalam, kuesioner yang ditujukan kepada responden, dan informan. Wawancara mendalam diarahkan melalui panduan pertanyaan wawancara. Data sekunder diperoleh dari dokumen-dokumen yang terkait dengan datadata mengenai topik penelitian yang didapatkan dari studi literatur yang berkaitan dengan tujuan penelitian seperti buku teks, artikel, skripsi, tesis, karya ilmiah, serta arsip/dokumen Pemerintah Kelurahan Surade dan Kampung Batusuhunan.

\section{Teknik Pengolahan dan Analisis Data}

Data kuantitatif yang diperoleh pada penelitian ini diperoleh merupakan data hasil kuesioner responden yang diolah dengan menggunakan program microsoft excel 2010. Data 
juga diolah dengan tabulasi silang dan dianalis secara statistik dengan uji statistik $\mathrm{t}$ yang menguji dua variabel dependen menggunakan software SPSS 16.0 For Windows. Uji statistik t ( $\mathrm{t}$ test) ini digunakan untuk menguji beda adanya perubahan antara kondisi ekologi, sosial, dan ekonomi sebelum dan setelah adanya ekowisata.

Selain analisis data kuantitatif, dilakukan pula analisis data kualitatif sebagai pendukung. Pendekatan kualitatif digunakan untuk memberikan penguatan dari data yang diperoleh melalui wawancara mendalam dan pengamatan. Gabungan data tersebut diolah dan dianalisis dengan disajikan dalam bentuk teks naratif, grafik, tabel, column chart atau bagan, kemudian ditarik kesimpulan dari semua data yang telah diolah.

\section{PROFIL LOKASI PENELITIAN}

\section{Kondisi Geografis, Topografis, dan Demografis Kelurahan Surade}

Secara administratif, Kampung Batusuhunan merupakan bagian dari wilayah Kelurahan Surade, Kabupaten Sukabumi, Provinsi Jawa Barat. Secara geografis Kelurahan Surade mempunyai luas $622,05 \mathrm{Ha}$, berada di sebelah selatan wilayah Kabupaten Sukabumi yang secara umum terbagi menjadi dua katagori lahan. Pertama, sebelah utara dan selatan yang mayoritas didominasi oleh lahan kering, perumahan, dan perkotaan. Kedua, sebelah barat dan timur didominasi oleh lahan basah pesawahan. Adapun batas- batas wilayahnya adalah sebagai berikut :

$\begin{array}{ll}\text { utara } & \text { : Desa Citangkar } \\ \text { timur } & \text { : Desa Jagamukti } \\ \text { selatan } & \text { : Desa Buniwangi dan Desa Pasiripis } \\ \text { barat } & \text { : Desa Kadaleman }\end{array}$

Kelurahan Surade berjarak $63 \mathrm{~km}$ dari Ibu Kota kabupaten Sukabumi, sedangkan dari Ibu kota Provinsi berjarak 217.5 km. Kondisi Topografi Kelurahan Surade memiliki ketinggian 116 meter di atas permukaan laut (dpl) dan secara umum wilayah Kelurahan Surade memiliki ketinggian berkisar antara 15-300 meter dpl. Rata-rata suhu udara berkisar antara 150C-250C, dengan suhu rata-rata 260C. Bentuk permukaan tanah (morfologi) relatif datar diseluruh bagian Kelurahan, baik di bagian utara, timur, selatan maupun barat wilayah Kelurahan Surade.

Secara demografi, jumlah penduduk Kelurahan Surade Kecamatan Surade cenderung tetap dengan mutasi lahir, mati, pindah datang dan pindah pergi. Pada Bulan Januari 2013 ini penduduk Kelurahan Surade berjumlah 9289 Jiwa dengan jumlah Kepala Keluarga sebanyak 2762 KK.

\section{Kondisi Infrastruktur Kelurahan Surade}

Ketersediaan sarana infrastruktur di Kelurahan Surade sudah cukup memadai dari sarana peribadatan, kesehatan, hingga pendidikan. Untuk sarana pendidikan, tersedia delapan PAUD, dua Taman Kanak-kanak, enam Sekolah Dasar, delapan Madrasah, dua SMK Swasta, tujuh Pondok Pesantren, dan dua Perguruan Tinggi Swasta. Sarana kesehatan terdiri dari satu Puskesmas, 12 Posyandu, empat Klinik Dokter, dan satu Poskesdes. Terdapat 28 masjid dan 46 mushola yang didirikan di Kelurahan Surade yang mayoritas penduduknya beragama Islam, sedangkan untuk umat kristiani biasanya beribadah di Desa Ujung Genteng karena Kelurahan Surade tidak memiliki gereja

\section{Gambaran Umum Kampung Batusuhunan}

Kampung Batusuhunan terletak di RW 08 Kelurahan Surade yang terdiri dari lima RT yaitu, RT 12, 14, 16, dan 17. Wilayah Kampung Batusuhunan dapat ditempuh dengan berbagai jenis kendaraan, baik kendaraan roda dua maupun roda empat. Kampung Batusuhunan berada di pinggiran Kelurahan Surade dengan jarak tempuh tiga $\mathrm{km}$. Tidak ada transportasi umum layaknya angkot untuk menuju kampung ini, namun terdapat ojek motor dengan tarif sebesar Rp 5000 dengan kondisi jalan yang rusak dan berbatu. Kampung ini memiliki 107 jiwa penduduk yang terbagi ke dalam $33 \mathrm{KK}$ dengan jumlah pria 54 jiwa (50.5 persen) dan wanita 53 jiwa (49.5 persen). Nama Batusuhunan berasal dari bentuk batu-batu yang bersusun di tengah bendungan yang ada di kampung ini, susunan batu ini berbentuk seperti rumah sehingga masyarakat memberi nama Batusuhunan (batu yang bersusun) untuk kampung ini. Kampung Batusuhunan memiliki potensi wisata yang masih alami, yaitu:

1. Air terjun (curug) Luhur yang menggunakan aliran air sungai cigangsa, pada curug ini terdapat tiga undak yaitu, leuwi mariuk yang paling atas, undak tengah, dan di undak paling bawah terdapat batu masigit yang dianggap keramat oleh masyarakat. Dahulu, di batu masigit inilah tempat berkumpul dan beribadah para wali.

2. Area Persawahan yang terdapat diantara pemukiman warga dan curug cigangsa.

3. Leuwi Kanyere dan Leuwi Bali

4. Curug Jawa dan Curug Nusa, Nusa adalah delta atau pulau kecil yang terdapat di tengah sungai.

5. Batu tonjong, yang merupakan dinding batu sungai cigangsa yang memiliki panjang $+200 \mathrm{~m}$, batu tonjong ini mirip dengan green canyon.

6. Curug anjung merupakan curug yang tidak terlalu dalam tetapi seluruh permukaannya merupakan batu hijau.

7. Saluran irigasi cigangsa, saluran ini menggunakan air yang berasal dari aliran sungai cigangsa untuk mengairi sawah petani. Kedalaman saluran irigasi ini kurang dari $1 \mathrm{~m}$ sehingga potensial untuk dipergunakan sebagai salah satu sarana permainan mini arum jeram dengan nama "papalidan".

\section{Ekowisata Berbasis Masyarakat Kampung Batusuhunan}

Konsep ekowisata berbasis masyarakat yang diterapkan di Kampung Batusuhunan dapat dijelaskan dengan teori yang dikemukakan oleh WWF (2009). menurut WWF Indonesia (2009), ekowisata berbasis masyarakat merupakan usaha ekowisata yang menitikberatkan peran aktif masyarakat. Hal tersebut didasarkan kepada kenyataan bahwa masyarakat memiliki pengetahuan tentang alam serta budaya yang menjadi potensi dan nilai jual sebagai daya tarik wisata, sehingga pelibatan masyarakat menjadi mutlak. Partisipasi masyarakat dalam menfelola ekowisata dapat dilihat dari tahap perencanaan, pelaksanaan, hingga evaluasi kegiatan ekowisata.

\section{Tahap Perencanaan}

Implementasi ekowisata perlu dipandang sebagai bagian dari perencanaan pembangunan terpadu yang dilakukan di suatu daerah. Untuk itu, pelibatan para pihak terkait mulai dari 
level komunitas, masyarakat, pemerintah, dunia usaha dan organisasi non pemerintah diharapkan membangun suatu jaringan serta menjalankan suatu kemitraan yang baik sesuai peran dan keahlian masing masing.

Pada awalnya, pemerintah yang menginisiasi masyarakat untuk bersama-sama membuka kawasan Curug Cigangsa sebagai tempat wisata. Namun masyarakat menolak untuk pembangunan area wisata karena khawatir akan ada pengaruhpengaruh negative yang dibawa oleh wisatawan ke dalam kampung mereka. Namun, setelah ada perbincangan lebih mendalam antara pemerintah, tokoh masyarakat, dan masyarakat Kampung Batusuhunan akhirnya pembukaan kawasan wisata disetujui tetapi dengan syarat bahwa jenis wisata yang ditawarkan adalah "Ekowisata Islami" sehingga segala tingkah laku wisatawan yang ada harus sesuai dengan kaidah-kaidah islam. Mengingat mayoritas masyarakat Kampung Batusuhunan beragama islam dan untuk menghindari hal-hal yang buruk kedepannya.

\section{Tahap Pelaksanaan}

Pola ekowisata berbasis masyarakat mengakui hak masyarakat lokal dalam mengelola kegiatan wisata di kawasan yang mereka miliki secara adat ataupun sebagai pengelola. Dengan adanya pola ekowisata berbasis masyarakat bukan berarti masyarakat akan menjalankan usaha ekowisata sendiri. Pembangunan sarana prasarana ekowisata dimulai sejak tahun 2010 dengan dana dari pemerintah sebesar 300 juta Rupiah dan 75 juta Rupiah dari swadaya masyarakat. pembangunan ekowisata, baik pria maupun wanita ikut bekerjasama membuat sarana dan prasarana menuju Curug Cigangsa seperti jalan tangga menuju curug, pengaspalan jalan, membuat gapura, menyediakan tong sampah, dan menanam pohon. Pada saat pengambilan keputusan yang berkaitan dengan ekowisata, pengurus ekowisata selalu mengundang seluruh masyarakat untuk diikutsertakan dalam musyawarah sehingga semua kegiatan pelaksanaan ekowisata juga diketahui oleh masyarakat setempat dan mereka ikut merasa memiliki ekowisata Curug Cigangsa. Akhirnya, pada tahun 2012 pembangunan sarana dan prasarana selesai dan selama masa pembangunan itu pula ekowisata Islami Curug Cigangsa mulai di buka sebagai ekowisata yang berada di kawasan Kampung Batusuhunan. Pada bulan November 2012, ekowisata ini dibuka secara resmi oleh Pemerintah Daerah Kecamatan Surade dan Kelurahan Surade.

\section{Tahap Evaluasi}

Ekowisata yang dikembangkan untuk kepentingan pembangunan berkelanjutan, yaitu sebuah kegiatan usaha yang bertujuan untuk menyediakan alternatif ekonomi secara berkelanjutan bagi masyarakat di kawasan ekowisata. Pengurus ekowisata Kampung Batusuhunan melakukan tahap evaluasi dengan mengundang seluruh masyarakat untuk melakukan musyawarah bersama. Hal ini dilakukan untuk memonitoring kegiatan ekowisata dan sebagai pertanggungjawaban pengurus agar ekowisata yang dijalankan dapat terus berkembang dengan baik. Hasil dari keuntungan ekowisata digunakan untuk biaya perawatan fasilitas ekowisata dan disumbangkan untuk masyarakat Kampung Batusuhunan.

\section{Sejarah Ekowisata Curug Cigangsa}

Pada awalnya, Curug Cigangsa yang berada di Kampung Batusuhunan bukanlah lokasi ekowisata. Pada tahun 1997 organisasi kepemudaan BALADAKA Kecamatan Surade mengusulkan untuk membangun kawasan wisata di Curug Cigangsa. Namun, rencana tersebut tidak diizinkan oleh tokoh adat setempat yaitu, Pak HBY. Alasannya adalah Curug Cigangsa merupakan kawasan keramat peninggalan nenek moyang yang harus dijaga, beliau khawatir akan terjadi kerusakan yang dilakukan oleh para wisatawan yang berkunjung ke Curug Cigangsa nantinya. Selain itu, jika dijadikan tempat wisata tidak menutup kemungkinan akan didirikan penginapan dan vila untuk menginap, beliau pun tidak mengizinkan dengan alasan mencegah pengaruh negatif yang dibawa oleh wisatawan ke kampung mereka. Pengaruh yang dibawa wisatawan ada yang bersifat negatif maupun positif sehingga masyarakat harus dapat memilah dengan tepat yang baik dan buruk seperti cara berpakaian, gaya hidup, dan cara berbicara wisatawan. Pengaruh ini akan masuk ke lingkungan masyarakat setempat dan akan mempengaruhi kondisi lingkungan yang hingga kini masih terjaga norma dan adatnya. Kemudian selang beberapa tahun, dibuatlah Rencana Tindak Penataan Lingkungan dan Pemukiman (RTPLP) yang tertuang dalam Peraturan Menteri Pekerjaan Umum No. 06/ PRT/M/2007. Peraturan ini berisi tentang niat pemerintah daerah yang mulai tertarik untuk membangun kawasan wisata di Kampung Batusuhunan. Namun, dengan alasan yang sama masyarakat dan tokoh adat setempat menolak rencana tersebut.

Hingga pada tahun 2010, melalui PLP-BK (Penataan Lingkungan Permukiman Berbasis Komunitas) pemerintah mulai mengajak masyarakat untuk bersama-sama membuka kawasan Curug Cigangsa sebagai tempat wisata. PLPBK ialah lembaga yang dibentuk oleh pemerintah pusat dan ditempatkan di enam kabupaten tiap provinsi. Tujuan utama pembentukan PLP-BK adalah untuk menciptakan tatanan kehidupan dan hunian yang tertata secara selaras, sehat, produktif, berjati diri, dan berkelanjutan. Fokus utama PLP-BK adalah pada penguatan dan pengembangan sosial kapital melalui pengokohan nilai-nilai universal dan kearifan lokal, penguatan pelayanan masyarakat di bidang ekonomi, lingkungan, sosial, serta membuka ruang kreativitas dan inovasi di masyarakat untuk menciptakan sumberdaya pembangunan pemukiman. Ciri utama PLPBK ialah Community Based Management, yakni menangani persoalan pemukiman melalui perencanaan, pelaksanaan, serta pengelolaan hasil-hasil pembangunan yang dipelihara dan dikelola oleh masyarakat setempat.

Setelah melalui proses yang cukup lama dan kesepakatan bersama, akhirnya masyarakat Kampung Batusuhunan setuju apabila kawasan ini dibuka untuk umum dengan syarat jenis wisata yang ditawarkan adalah "Ekowisata Islami" sehingga segala tingkah laku wisatawan yang ada harus sesuai dengan kaidah- kaidah islam. Mengingat mayoritas masyarakat Kampung Batusuhunan beragama islam dan untuk menghindari hal-hal yang buruk kedepannya.

Hasil penelitian Adelia (2012) menjelaskan bahwa Ekowisata Islami yang ditawarkan di Curug Cigangsa dikembangkan dan dikelola berdasarkan mitos dan norma yang dipercaya dan dianut masyarakat setempat. Norma dan mitos tersebut sejalan dengan aturan-aturan yang diajarkan oleh agama islam. Dengan adanya mitos dan norma maka terbangun tata aturan/ pedoman dalam mengelola ekowisata. Mitos, norma dan aturan adat lokal yang berbasis islam dianggap dapat menjadi penangkal dampak negatif yang mungkin hadir seiring dengan hadirnya wisatawan ke lokasi tersebut. Norma-norma dan mitos-mitos yang dipercaya dan diyakini masyarakat bersifat turun-temurun diperoleh dari para nenek moyang yang ada 
di Kampung Batusuhunan. Masyarakat yang mendiami Kampung Batusuhunan merupakan masyarakat asli yang sudah dari dulu mendiami kawasan tersebut, sehingga segala peraturan, norma dan mitos yang ada juga bersifat turuntemurun dan mendarah daging dalam diri masyarakat.

Pengembangan suatu kawasan menjadi kawasan ekowisata didorong oleh adanya harapan dari beberapa pihak untuk kemajuan ekonomi masyarakat dan wilayah ekowisata. Masyarakat Batusuhunan sebagai aktor utama dari kegiatan ekowisata di Curug Cigangsa memiliki harapan yang tinggi dalam aspek ekonomi dibandingkan dengan aspek ekologi juga sosial budaya. Hal ini terjadi karena masyarakat menginginkan adanya peningkatan pendapatan baik untuk masing-masing individu maupun untuk Kampung Batusuhunan secara keseluruhan. Harapan terhadap aspek ekonomi yang menjadi pendorong paling besar pada masyarakat untuk menyetujui pengembangan kawasan ekowisata.

\section{Pengelolaan Ekowisata Berbasis Masyarakat}

Bentuk ekowisata yang ditawarkan di Curug Cigangsa konsep Ekowisata Islami yang dikelola berbasis masyarakat Segala peraturan yang terdapat di lokasi ekowisata telah disesuaikan dengan kaidah- kaidah islam dan adat masyarakat setempat di lokasi ekowisata ini. Walaupun belum sepenuhnya mengikuti kaidah islam, akan tetapi segala norma yang dibuat sudah berpedoman pada kaidah-kaidah islam. Masyarakat sebagai pengelola pun berupaya optimal untuk membangun dan merawat kawasan ekowisata agar menjadi lebih baik dan nyaman dikunjungi wisatawan. Objek daya tarik yang diunggulkan adalah ekowisata Curug Cigangsa yang menawarkan atraksi wisata tempat bermain, penyimpanan benda cagar budaya, irigasi, dan pemancingan. Selain itu, terdapat produk-produk khas untuk souvenir dan makanan khas seperti opak, gula kelapa, dan keripik singkong.

Pada tahun 2010, setelah adanya persetujuan untuk membuka kawasan ini menjadi kawasan ekowisata dari masyarakat setempat, pemerintah Kelurahan Surade mulai mengajukan proposal dana kepada pemerintah daerah Kabupaten Sukabumi untuk melakukan pembangunan infrastruktur di kawasan Curug Cigangsa yang sebelumnya masih sangat alami. Bantuan awal yang diberikan oleh pemerintah kabupaten melalui PLP-BK ialah berjumlah sekitar 300 juta Rupiah. Ditambah lagi dengan iuran swadaya oleh masyarakat Kampung Batusuhunan yang mencapai 75 juta Rupiah. Sehingga total biaya pembangunan infrastruktur kawasan ekowisata sebesar 375 juta Rupiah. Dana tersebut dialokasikan untuk membangun jalan setapak dan tangga-tangga kecil yang dapat memudahkan wisatawan untuk mengunjungi Curug Cigangsa. Masyarakat juga membuat tiga buah tempat bersantai dan istirahat di tiga titik kawasan Curug Cigangsa. Selain itu, masyarakat sudah menyiapkan tiga bangunan tempat pembuangan sampah akhir, beserta beberapa tong sampah yang disimpan di sekitar Curug Cigangsa. Bantuan dana tersebut juga digunakan untuk membuat dua buah toilet umum dan bangunan loket untuk pembelian tiket. Keberadaan Lembaga PLP-BK sebagai fasilitator antara pemerintah dengan masyarakat yang mengelola ekowisata berakhir pada September 2012. Masa aktif kepengurusan PLP-BK sudah berakhir dan belum ada pergantian kepengurusan kembali hingga pada saat dilakukannya penelitian.

Sampai saat ini, kepengurusan ekowisata masih dipegang oleh masyarakat setempat dengan struktur yang sederhana. Kepengurusan diketuai oleh tokoh yang dihormati di
Kampung Batusuhunan yaitu Pak HBY. Kemudian sekretaris dan bendahara yang di jabat masing-masing oleh Pak WAN dan Ibu ROR. Struktur kepengurusan ekowisata berbasis masyarakat di Kampung Batusuhunan dapat dijelaskan sebagai berikut, ketua ekowisata sekaligus sebagai tokoh yang dihormati oleh masyarakat setempat berperan sebagai wakil dari masyarakat yang dipercayai dan penasehat ekowisata yang mengarahkan pengelolaan jalannya ekowisata agar tetap pada aturan-aturan islami. Sekretaris berperan dalam mengurus berkas proposal pengajuan dana, surat-surat undangan rapat, dan laporan pertanggungjawaban mengenai pengelolaan ekowisata. Bendahara berperan dalam mengumpulkan keseluruhan dana yang masuk untuk pengelolaan ekowisata. Dana pengelolaan ekowisata sendiri berasal dari bantuan pemerintah uang tiket masuk sebesar Rp $2000 /$ tiket. Apabila ada yang memakai jasa guide sebesar Rp 25000 , sebanyak 20 persen akan disumbangkan ke dalam uang kas yang dikumpulkan ke bendahara. Uang kas ini nantinya akan dibagi kepada seluruh KK (33 KK) pada saat Idul Fitri. Masyarakat Kampung Batusuhunan sendiri terlibat dalam kegiatan ekowisata dengan berperan sebagai tour guide, menyediakan katering, membuat gula kelapa sebagai oleh-oleh khas Kampung Batusuhunan, serta menjual es kelapa. Selain itu, masyarakat juga berkewajiban untuk tetap merawat kawasan ekowisata. Seperti bekerja bakti membersihkan kampung, menanam pohon, membersihkan toilet umum, dan membuang sampah pada tempatnya.

\section{Karakteristik Responden}

Karakteristik penduduk yang dijadikan responden dalam penelitian ini adalah Masyarakat Kampung Batusuhunan yang terlibat dalam kegiatan ekowisata. Responden yang terlibat terdiri atas pengurus ekowisata, penjual kue, pembuat gula kelapa, usaha warung, pemandu wisata, dan penjual gula kelapa. Kegiatan ekowisata yang dilakukan oleh responden ada yang berupa pekerjaan utama responden dan ada pula yang menjadi usaha sampingan bagi responden. Pembagian ini dimaksudkan untuk melihat pengaruh ekologi, sosial, dan ekonomi yang dirasakan oleh masyarakat langsung semenjak adanya ekowisata. Semua responden yang terpilih merupakan warga asli Kampung Batusuhunan yang sudah menempati Kampung Batusuhunan selama kurun waktu yang lama sehingga sudah mengenal Kampung Batusuhunan dengan sangat baik. Kampung Batusuhunan terletak di RW 08 yang terdiri atas lima RT yaitu, RT 11, 12, 14, dan 17 yang memiliki jumlah penduduk 107 jiwa. Dari 107 jiwa tersebut, terdapat 34 orang yang menjadi responden dalam penelitian ini.

Berdasarkan jenis pekerjaan, 34 responden yang terpilih juga memiliki berbagai jenis pekerjaan yang berbeda. Terdapat delapan kelompok pekerjaan, antara lain wiraswasta, PNS, petani, penjual kue, pembuat gula, guru, pedagang warung dan ibu rumahtangga. Pekerjaan tersebut merupakan pekerjaan utama responden. Responden terbanyak ialah bekerja sebagai petani (29 persen). Pekerjaan responden yang terbanyak selanjutnya adalah pedagang warung (18 persen). Kemudian responden selanjutnya bekerja di rumah sebagai ibu rumahtangga (17 persen). Terdapat pembuat gula (15 persen), wiraswasta (sembilan persen), dan guru (enam persen). Sisanya sebagai penjual kue (tiga persen). dan PNS (tiga persen).

Setelah adanya ekowisata, kesempatan lapangan kerja di bidang ekowisata menjadi muncul dan mendorong masyarakat Kampung Batusuhunan untuk meningkatkan 
penghasilannya. Terdapat delapan jenis pekerjaan yang dapat menjadi tambahan penghasilan masyarakat di bidang ekowisata antara lain penjual es kelapa (lima persen), katering (16 persen), pedagang warung (21 persen), penjual kue (lima persen), penjual ikan (lima persen), pembuat gula (16 persen), penjual sayur (11 persen), dan pengelola ekowisata (21 persen). Tingkat pendidikan responden merupakan salah satu aspek penting dalam mengelola ekowisata.Tingkat pendidikan berpengaruh terhadap keterampilan, pengetahuan, dan kualitas SDM (Sumber Daya Manusia) yang kedepannya akan mengelola ekowisata. Semakin tinggi pendidikan masyarakat maka diharapkan pengelolaan ekowisata akan semakin baik.

Tingkat pendidikan di Kampung Batusuhunan terbagi ke dalam empat kategori tingkatan, yaitu SD, SMP, SMA dan Sarjana (S1). Responden yang hanya menempuh pendidikan sampai tingkat Sekolah Dasar paling banyak dibandingkan tingkat pendidikan lainnya yaitu 62 persen. Persentase jumlah responden yang menempuh tingkat pendidikan hingga SMP dan SMA masing-masing berjumlah 23 persen dan 12 persen. Responden yang menempuh pendidikan sampai Perguruan Tinggi berjumlah tiga persen.

\section{PERUBAHAN KONDISI EKOLOGI KAMPUNG}

\section{BATUSUHUNAN}

Ekowisata merupakan pariwisata yang mengedepankan aspek konservasi ekologi. Untuk itu, keberlanjutan ekowisata ditentukan oleh aspek ekologi. Adanya ekowisata mempengaruhi kehidupan masyarakat di sekitar kawasan ekowisata, dalam kasus ini adalah masyarakat Kampung Batusuhunan. Keterlibatan masyarakat dalam menjaga kelestarian lingkungan akan mempengaruhi perkembangan ekowisata. Bab ini akan membahas mengenai bagaimana kondisi ekologi sebelum dan setelah adanya ekowisata di Kampung Batusuhunan yang dilihat dari perilaku keterlibatan masyarakat dalam menjaga kelestarian lingkungan.

\section{Kondisi Ekologi Masyarakat Sebelum Adanya Ekowisata}

\section{Sanitasi dan Air bersih}

Kebutuhan akan air bersih merupakan salah satu kebutuhan utama masyarakat. Air di Kecamatan Surade sudah tidak dapat digunakan untuk keperluan minum karena airnya sudah mulai tercemar sehingga keperluan air minum menggunakan air isi ulang dan air kemasan. Berbeda dengan Kecamatan Surade, Kampung Batusuhunan belum dapat dijangkau oleh fasilitas PDAM untuk kebutuhan air sehari-hari. Walaupun demikian, Kampung Batusuhunan memiliki sumber air bersih yang cukup tersedia untuk masyarakatnya. Sumber air di kampung ini masih bersih dan belum tercemar sehingga penggunaan air bersih dan MCK (Mandi Cuci Kakus) diambil dari sungai dan air tanah yang melalui sumur. Air ini bersumber dari sumur gali dan sumur pompa sebagai sumber air bersih. Masyarakat masih memasak air ini untuk digunakan sebagai air minum. Selain itu, terdapat pula air yang bersumber dari sungai, biasanya air ini dimanfaatkan untuk pertanian dan perikanan masyarakat sekitar. Untuk sarana sanitasi, di setiap rumah masing- masing sudah memiliki MCK sendiri, namun masyarakat kampung ini masih sering terlihat menggunakan toilet umum untuk keperluan mandi dengan alasan lebih nyaman digunakan. Selain itu, masyarakat yang khususnya ibu rumahtangga lebih senang mencuci pakaian dan mandi di sungai karena airnya bersih.

\section{Pengolahan Sampah}

Masyarakat Batusuhunan memiliki kebiasaan untuk mengolah limbah sampah rumah tangga dengan cara dibakar. Sampah-sampah rumahtangga dikumpulkan menjadi satu dan kemudian dibakar. Belum adanya pengolahan sampah secara khusus yang dilakukan oleh pengurus Kampung Batusuhunan sebelum adanya pengembangan ekowisata. Kesadaran masyarakat untuk tidak membuang sampah sembarangan dan menjaga lingkungan kampung agar tetap bersih dapat dilihat melalui kerja bakti yang diselenggarakan satu minggu sekali. Biasanya acara kerja bakti ini diadakan pada hari libur agar seluruh warga dapat berpartisipasi di dalamnya.

\section{Tingkat Kelestarian Lingkungan}

Masyarakat Batusuhunan sadar akan menjaga kelestarian lingkungan kampung. Keterlibatan masyarakat dalam menjaga kelestarian lingkungan ini meliputi gaya hidup ramah lingkungan, pengelolaan sampah, menanam pohon, dan mematuhi peraturan yang ada di kawasan Kampung Batusuhunan untuk menjaga lingkungan. Masyarakat telah memiliki kesadaran akan pentingnya alam dan lingkungan akan senantiasa menjaganya. Selain itu, masyarakat beranggapan bahwa dengan menjaga lingkungan mereka akan menerima manfaat yang baik pula dari lingkungan.

Gaya hidup ramah lingkungan yang dilakukan oleh masyarakat Batusuhunan yaitu, lebih senang berjalan kaki apabila melakukan perjalanan dekat seperti berkunjung ke rumah tetangga di kampung sebelah dan pergi berbelanja ke pasar, hal ini dapat mengurangi polusi udara akibat kendaraan bermotor yang merupakan transportasi utama di Batusuhunan. Di halaman rumah masyarakat pun menanam pohon seperti mangga atau beringin dan tanaman obat keluarga, yang akan membuat suasana Kampung Batusuhunan menjadi lebih asri. Masyarakat juga mematuhi aturan dan mitos yang dilarang dilakukan di kawasan Curug Cigangsa.

\section{Kondisi Ekologi Mayarakat Setelah Adanya Ekowisata}

\section{Sanitasi dan Air bersih}

Keadaan sanitasi dan air bersih di Kampung Batusuhunan saat ini (2013) tidak jauh berbeda dengan keadaan tiga tahun lalu (2010) sebelum adanya ekowisata. Menurut masyarakat setempat, air di kampung ini masih bersih dan belum tercemar sehingga penggunaan air bersih dan MCK (Mandi Cuci Kakus) diambil dari sungai dan air tanah. Air ini bersumber dari sumur gali dan sumur pompa sebagai sumber air bersih. Masyarakat masih memasak air ini untuk digunakan sebagai air minum. Selain itu, terdapat pula air yang bersumber dari sungai, biasanya air ini dimanfaatkan untuk pertanian dan perikanan masyarakat sekitar.

\section{Pengelolaan Sampah}

Setelah adanya pengembangan ekowisata, terjadi perubahan perilaku dan pengetahuan masyarakat tentang sampah dan pengelolaannya. Masyarakat sadar apabila lokasi Kampung Batusuhunan telah dijadikan ekowisata, akan ada wisatawan yang masuk ke kawasan kampung dan beraktivitas yang biasanya menimbulkan sampah makanan. Sampah yang dihasilkan Kampung Batusuhunan akan bertambah banyak 
karena ditambah oleh sampah yang dihasilkan para wisatawan. Masyarakat mulai belajar untuk mengelola dan mendaur ulang sampah. Masyarakat mulai mengelola sampah melalui tempat sampah khusus untuk membedakan jenis sampah. Disediakan 3 jenis tempat sampah yang berbeda, yaitu tempat sampah khusus plastik dan kertas (anorganik), tempat sampah basah dan sayuran yang bisa membusuk (organik), dan tempat sampah terakhir untuk sampah yang tidak termasuk ke dalam kategori organik dan anorganik (residu). Sampah yang telah dipisahkan kemudian dikumpulkan ke dalam tempat sampah yang berada di dekat rumah masingmasing.

Pengangkutan dari tiap-tiap rumah tangga dilakukan oleh petugas yang telah ditunjuk oleh warga ke TPS (Tempat Pembuangan Sementara). Untuk sistem pengangkutan dan pembuangan akhir ditarik oleh petugas dengan gerobak atau motor sampah. Selain itu, sebagian masyarakat Batusuhunan juga mendaur ulang sampah menjadi tas, dompet, dan hiasan rumah seperti gorden dari sampah jenis plastik. Namun untuk jenis sampah organik, yaitu berupa daun kering, sisa sayuran, dan buah-buahan masyarakat belum mengolahnya menjadi pupuk organik untuk tanaman mereka karena tidak mengetahui cara mengolahnya.

\section{Tingkat Kelestarian Lingkungan}

Aspek lingkungan yang alamiah dalam ekowisata merupakan aspek utama ciri khas ekowisata. Manusia hidup bergantung dengan lingkungan, begitu pula dengan lingkungan yang membutuhkan perawatan manusia. Keberlanjutan ekowisata juga bergantung pada lingkungan, maka masyarakat diharapkan dapat terlibat untuk merawatnya. Sebelum adanya ekowisata, kesadaran masyarakat Batusuhunan terhadap pentingnya menjaga kelestarian lingkungan sudah cukup tinggi. Masyarakat beranggapan bahwa dengan menjaga lingkungan mereka akan menerima manfaat yang baik pula dari lingkungan. Apabila lingkungan rusak tidak hanya generasi saat ini yang mengalami akibatnya, namun juga generasi mendatang yang akan merasakannya.

Melalui ekowisata berbasis masyarakat, seluruh warga batusuhunan bersama-sama membangun ekowisata dengan memperhatikan aspek lingkungan. Dengan dibukanya menjadi kawasan ekowisata, perlu adanya perubahan bagaimana cara mengelola kawasan yang dahulunya hanya kampung biasa menjadi kawasan ekowisata yang nantinya akan sering dikunjungi wisatawan yang keluar dan masuk kampung ini. Masyarakat telah memiliki kesadaran untuk menjaga lingkungan sehingga dapat menarik wisatawan untuk datang dan menjaga kelestarian lingkungan. Untuk lebih jelasnya, dapat dilihat pada Tabel 1.

Berdasarkan hasil Tabel 1, mengemukakan bahwa terdapat perubahan yang signifikan terhadap keterlibatan responden dalam menjaga kelestarian lingkungan. Awalnya jumlah responden yang tergolong dalam kategori rendah sebesar 17.6 persen (enam responden), kemudian mengalami perubahan menjadi 8.8 persen (tiga responden) setelah adanya ekowisata. Perubahan persentase responden adalah sebesar 8.8 persen atau mengalami penurunan dari kondisi sebelum adanya ekowisata, artinya responden yang memiliki tingkat keterlibatan rendah semakin berkurang terhadap kelestarian lingkungan.
Tabel 1. Jumlah dan Persentase Responden Berdasarkan Perubahan Tingkat Kelestarian Lingkungan

\begin{tabular}{|c|c|c|c|c|c|}
\hline \multirow{2}{*}{$\begin{array}{l}\text { Tingkat } \\
\text { kelestarian } \\
\text { lingkungan }\end{array}$} & \multicolumn{2}{|l|}{ Sebelum } & \multicolumn{2}{|l|}{$\begin{array}{c}\begin{array}{c}\text { Sesu- } \\
\text { dah }\end{array} \\
\end{array}$} & \multirow{2}{*}{$\begin{array}{c}\Delta \\
(\%)\end{array}$} \\
\hline & $\Sigma$ (orang) & $\%$ & $\begin{array}{c}\Sigma \\
\text { (orang) }\end{array}$ & $\%$ & \\
\hline Tinggi & 28 & 82.4 & 31 & 91.2 & 8.8 \\
\hline Rendah & 6 & 17.6 & 3 & 8.8 & 8.8 \\
\hline $\begin{array}{l}\mathrm{J} \text { u m } 1 \text { a } \mathrm{h} \\
\text { Rataan }\end{array}$ & 34 & 100 & 34 & 100 & \\
\hline Skor & 16.8 & & 17.7 & & \\
\hline
\end{tabular}

Perubahan yang nyata juga ditunjukkan oleh responden yang tergolong dalam kategori tinggi, awalnya jumlah responden yang memiliki tingkat keterlibatan tinggi sebesar 82.4 persen (28 responden), kemudian mengalami perubahan setelah adanya ekowisata sebesar 91.2 persen (31 responden). Perubahan persentase responden adalah sebesar 8.8 persen. Perubahan keterlibatan responden menjadi meningkat karena dipengaruhi oleh adanya ekowisata berbasis masyarakat di Kampung Batusuhunan. Masyarakat merasa bertanggungjawab menjaga kelestarian lingkungan kampung mereka agar nantinya ekowisata dapat berkelanjutan untuk generasi selanjutnya kelak.

Berdasarkan uji statistik $\mathrm{t}$ dengan nilai $\alpha$ sebesar 0.05 , diperoleh nilai signifikansi 0.00 serta nilai t hitung 5.374 lebih besar dari t tabel 2.021. Uji statistik sebesar 0.000 (< 5 persen) artinya terdapat beda nyata tingkat keterlibatan masyarakat dalam menjaga kelestarian lingkungan antara sebelum adanya ekowisata dan setelah adanya ekowisata di Kampung Batusuhunan. Terlihat bahwa setelah adanya ekowisata berbasis masyarakat di kampung ini, masyarakat lebih peduli dan semakin aktif terlibat dalam upaya menjaga kelestarian lingkungan.

\section{PERUBAHAN KONDISI SOSIAL KAMPUNG BATUSUHUNAN}

Masyarakat merupakan salah satu unsur penting dalam pengembangan ekowisata. Pada kasus ini, masyarakat Kampung Batusuhunan merupakan subjek dari ekowisata yang berperan dalam mengelola ekowisata. Hal ini memberikan mobilitas baru bagi masyarakat, sehingga hadirnya ekowisata dapat mempengaruhi proses sosial yang ada di Kampung Batusuhunan. Hubungan kerjasama, tolong menolong, dan kegiatan kemasyarakatan yang biasanya menjadi ciri khas dalam suatu kampung dapat mengalami perubahan semenjak adanya ekowisata. Perubahan tersebut dapat berupa hal yang positif apabila dengan hadirnya ekowisata, masyarakat menjadi semakin sering berinteraksi dengan masyarakat lainnya dan menciptakan kerjasama yang semakin erat. Namun sebaliknya, perubahan dapat berupa hal negatif apabila ekowisata meningkatkan aktivitas kerja penduduk dan mengakibatkan hubungan antara masyarakat semakin renggang bahkan dapat menimbulkan konflik karena persaingan yang terjadi dalam bidang ekowisata. Dalam bab ini akan membahas mengenai bagaimana perubahan kondisi sosial sebelum dan setelah adanya ekowisata di Kampung Batusuhunan yang dilihat dari proses sosial yaitu tingkat kerjasama masyarakat Kampung Batusuhunan dan apakah adanya ekowisata menimbulkan konflik diantara masyarakat. 
Kondisi Sosial Masyarakat Sebelum Adanya Ekowisata

\section{Tingkat Kerjasama Masyarakat}

Soekanto (1990) dalam Ayuningtyas (2011) mengemukakan bahwa interaksi sosial adalah hubungan-hubungan sosial yang dinamis yang menyangkut hubungan orang perorangan, antara kelompok-kelompok manusia maupun antara orang perorangan dengan kelompok manusia. Interaksi sosial ini ada yang bersifat mempersatukan atau mendekatkan dan ada yang menjauhkan atau mempertentangkan. Salah satu proses sosial yang mendekatkan yaitu kerjasama. Kerjasama berarti bekerja bersama dalam rangka mencapai sesuatu tujuan bersama. Istilah kerjasama disini adalah padanan kata cooperation (co: bersama; operate: bekerja) Adanya Kerjasama memang telah ada sejak dahulu di Kampung Batusuhunan. Sebelum adanya ekowisata, bentuk kerjasama yang ada di kampung ini dapat dilihat dari keterlibatan masyarakat dalam kegiatan pengajian, gotong royong, musyawarah, siskamling, dan upacara adat. Kerjasama berupa pengajian biasanya rutin dilakukan setiap satu minggu sekali. Untuk bapakbapak, diadakan setiap malam jumat. Sedangkan untuk ibu-ibu, diselenggarakan pada jumat sore. Untuk kegiatan gotong-royong yang meliputi perbaikan jalan, membantu tetangga yang sedang ada pesta hajatan ataupun mengalami kesulitan di kampung tersebut.

Musyawarah diadakan apabila akan diselenggarakan suatu acara di kampung ini dan ketika terdapat masalah di masyarakat yang harus didiskusikan bersama. Untuk siskamling, rutin dilaksanakan setiap malam yang dilakukan oleh bapak- bapak dan anak muda yang diatur dengan jadwal piket siskamling. Hampir seluruh masyarakat Kampung Batusuhunan beragama islam, maka tidak ada perayaan upacara adat khusus di kampung ini tetapi kerjasama untuk memperingati hari besar islam seperti maulid nabi, isra'miraj, idul fitri, dan idul adha. Contohnya saja saat mengadakan perayaan maulid nabi, masyarakat mengadakan pengajian dan ceramah di kampung ini. Para ibu-ibu bekerjasama untuk menyiapkan masakan yang dihidangkan seperti membuat kue-kue dan nasi tumpeng. Sedangkan bapak-bapak menyiapkan panggung, tempat, dan memantau acara selama kegiatan belangsung.

Eratnya hubungan antar masyarakat di Kampung Batusuhunan didukung dengan hubungan tali persaudaraan semenjak nenek moyang dahulu. Hampir satu kampung adalah keluarga dari satu garis keturunan yang sama dan menetap sejak lahir di Kampung Batusuhunan sehingga hubungan persaudaraannya masih sangat erat. Hubungan kekerabatan ini masing- masing saling menghargai dan menghormati. Kerjasama yang terjadi biasanya berupa saling tolong- menolong bila ada yang kekurangan, terkena musibah dan penyelenggaraan hajatan. Pekerjaan yang terasa berat jika dikerjakan seorang menjadi lebih ringan bila dikerjakan bersama-sama. Namun terdapat alasan lain yang dikemukakan oleh salah satu warga, yang mengikuti acara gotong royong di kampung karena merasa tidak enak dan malu jika tidak hadir membantu warga lainnya dalam gotong royong di kampung.

Kondisi Sosial Masyarakat Setelah Adanya Ekowisata

\section{Tingkat Kerjasama Masyarakat}

Kerjasama yang dilakukan di Kampung Batusuhunan sudah lama ada dan adanya ekowisata berbasis masyarakat dapat dikatakan tidak berpengaruh penting terhadap proses sosial di masyarakat. Kerjasama yang dilakukan berupa gotong royong untuk mencapai tujuan bersama. Dana yang digunakan dalam gotong royong ini berasal dari swadaya masyarakat sendiri. Adanya ekowisata membuat kegiatan kerjasama di masyarakat semakin meningkat. Untuk lebih jelasnya, dapat dilihat pada tabel 2 di bawah ini.

\section{Tabel 2. Jumlah dan Persentase Perubahan Tingkat Kerjasama Masyarakat Kampung Batusuhunan}

\begin{tabular}{|c|c|c|c|c|c|}
\hline \multirow{2}{*}{$\begin{array}{l}\text { Tingkat } \\
\text { kerjasama } \\
\text { kelestarian } \\
\text { lingkun- } \\
\text { gan }\end{array}$} & \multicolumn{2}{|l|}{ Sebelum } & \multicolumn{2}{|l|}{ Sesudah } & \multirow[b]{2}{*}{$\begin{array}{c}\Delta \\
(\%)\end{array}$} \\
\hline & $\Sigma$ (orang) & $\%$ & $\begin{array}{c}\Sigma \\
\text { (orang) }\end{array}$ & $\%$ & \\
\hline Tinggi & 28 & 82.4 & 30 & 88.2 & 5.8 \\
\hline Rendah & 6 & 17.6 & 4 & 11.8 & 5.8 \\
\hline $\begin{array}{l}\mathrm{J} \text { u m } 1 \text { a h } \\
\text { Rataan }\end{array}$ & 34 & 100 & 34 & 100 & \\
\hline Skor & 17.5 & & 17.6 & & \\
\hline
\end{tabular}

$\Delta($ delta $)=$ Perubahan tingkat kerjasama masyarakat Kampung Batusuhunan

Tabel 2 memperlihatkan perubahan tingkat kerjasama masyarakat yang diukur dengan keikutsertaan responden pada kegiatan gotong royong meliputi musyawarah, pengajian, dan siskamling. Ekowisata yang dikelola berbasis masyarakat memberikan kesempatan masyarakat setempat sebagai pelaku utama dalam kegiatan ekowisata. Aktivitas dalam bidang ekowisata dapat mempengaruhi masyarakat dalam tingkat kerjasama yang biasa masyarakat lakukan sebelum adanya ekowisata. Berdasarkan Tabel 2 , Awalnya jumlah responden yang tergolong dalam kategori rendah sebesar 17.6 persen (enam responden), kemudian mengalami perubahan menjadi 11.8 persen (empat responden) setelah adanya ekowisata. Perubahan persentase responden adalah sebesar 5.8 persen atau mengalami penurunan dari kondisi sebelum adanya ekowisata, artinya responden yang memiliki tingkat kerjasama tergolong rendah semakin berkurang semenjak adanya ekowisata.

Pada responden yang tergolong dalam kategori tinggi, awalnya jumlah responden yang memiliki tingkat kerjasama tinggi sebesar 82.4 persen (28 responden), kemudian mengalami perubahan setelah adanya ekowisata sebesar 88.2 persen (30 responden). Perubahan persentase responden adalah sebesar 5.8 persen. Perubahan tingkat kerjasama responden menjadi meningkat karena dipengaruhi oleh adanya ekowisata berbasis masyarakat di Kampung Batusuhunan. Berdasarkan uji statistik t dengan nilai $\alpha$ sebesar 0.05 , diperoleh nilai signifikansi 0.023 serta nilai thitung 3.385 (Lampiran 6). lebih besar dari t tabel 2.021. Uji statistik sebesar $0.023(<5$ persen) artinya terdapat beda nyata tingkat kerjasama masyarakat sebelum adanya ekowisata dan setelah adanya ekowisata di Kampung Batusuhunan.

\section{PERUBAHAN KONDISI EKONOMI KAMPUNG}

\section{BATUSUHUNAN}

Untuk meningkatkan pengembangan ekowisata,tidak hanya 
kebutuhan alam yang harus diperhatikan, tetapi juga kebutuhan masyarakat setempat. Konsep ekowisata berbasis masyarakat mengakui hak masyarakat lokal dalam mengelola kegiatan wisata. Ekowisata berbasis masyarakat dapat menciptakan kesempatan kerja bagi masyarakat setempat dan menambah penghasilan sehingga dapat mengurangi kemiskinan dan meningkatkan taraf hidup masyarakat setempat. Tidak saja mendapatkan pekerjaan dan peningkatan pendapatan, masyarakat juga dapat menciptakan suatu lapangan pekerjaan baru yang menunjang kegiatan ekowisata. Dalam bab ini akan membahas mengenai bagaimana perubahan kondisi ekonomi masyarakat Kampung Batusuhunan sebelum dan setelah adanya ekowisata. Perubahan kondisi ekonomi dilihat dari perubahan tingkat pendapatan karena usaha ekowisata dan perubahan taraf hidup masyarakat setempat.

\section{Kondisi Ekonomi Masyarakat Sebelum Adanya Ekowisata Mata Pencaharian Masyarakat}

Pekerjaan masyarakat di Kampung Batusuhunan cukup beragam. Mulai dari petani, PNS, penjual kelapa muda, pembuat gula kelapa, penjual ayam bakar dan ikan bakar, tukang ojek, dan warung. Kebanyakan dari masyarakat adalah petani. Hal ini didukung oleh kondisi lahan pertanian yang masih subur. Jenis pertanian yang ditanam adalah padi sawah dan sayur- sayuran. Petani di Kampung Batusuhunan masih memiliki lahan pertanian sendiri, mereka tidak akan menjual lahan pertaniannya karena lahan tersebut merupakan peninggalan orang tua mereka dan akan diwariskan kembali untuk anak cucunya kelak.

Di kampung ini, masyarakatnya terkenal sebagai pembuat gula kelapa. Gula kelapa adalah ciri khas dari Kampung Batusuhunan. Pembuatan gula kelapa dilakukan oleh satu rumah tangga yang menjalankan profesi ini. Mereka membuat dapur kecil di halaman rumah sebagai dapur khusus untuk membuat gula kelapa. Dalam satu hari, satu rumah tangga bisa menghasilkan hingga delapan kilogram. Satu kilogram gula kelapa dihargai sebesar Rp 6000 yang dijual kepada tengkulak. Dari tengkulak, biasanya gula dibawa ke pabrik gula kelapa yang lebih besar yang terdapat di Surade. Setelah itu, gula dibentuk dan dikemas untuk dijual ke pasar. Harga gula kelapa terkadang berubah, tergantung kualitas gula kelapa yang dihasilkan. Jika musim hujan, biasanya kualitas gula kelapa menjadi jelek dan harganya bisa turun hingga $\mathrm{Rp} 4$ 000/kg. Namun jika musim kemarau, kualitas gula menjadi bagus dan harganya pun dapat mencapai Rp 10 000/ $\mathrm{kg}$.

Selain petani dan pembuat gula, masyarakat di kampung ini berprofesi sebagai PNS. Ada yang menjadi pegawai kelurahan, kecamatan, dan KUA. Namun kebanyakan adalah menjadi guru di SD, SMP, dan SMA. Masyarakat juga membuka usaha seperti berjualan ayam bakar dan ikan bakar, tukang ojek, serta usaha warung.

\section{Tingkat Pendapatan Rumahtangga}

Kampung Batusuhunan merupakan salah satu kampung di Kecamatan Surade yang tingkat perekonomiannya tergolong rendah sehingga salah satu cara untuk meningkatkan perekonomian kampung ini pemerintah daerah menetapkan sebagai kawasan ekowisata. Sebelum adanya ekowisata, rata-rata tingkat pendapatan masyarakat adalah Rp 1367353. Namun, untuk menggolongkan tingkat pendapatan dengan ukuran rata-rata tersebut tidak dapat mewakili gambaran seluruh responden di kampung ini. Pendapatan terendah di kampung ini adalah sebesar Rp 250000 dan untuk pendapatan tertinggi sebesar Rp 5000000 .

Peneliti menggolongkan tingkat pendapatan masyarakat Batusuhunan menjadi 3 kategori, yaitu tinggi, sedang, dan rendah. Kategori tersebut dapat diperoleh melalui inverval kelas yang dihitung dengan rumus interval kelas. Dari hasil perhitungan, didapat Rp 1583333.33 sebagai interval kelas untuk rata-rata pendapatan masyarakat Kampung Batusuhunan. Sehingga, tingkat pendapatan dapat dikategorikan sebagai berikut:

1. $\quad$ Rp 3416666.67 - Rp $5000000.00=$ tingkat pendapatan per bulan tergolong "Tinggi" = skor 3

2. $\operatorname{Rp} 1833 \quad 333.34$ - Rp $3416666.66=$ tingkat pendapatan per bulan tergolong "Sedang" $=$ skor 2

3. $\quad$ Rp 250000.00 - Rp 1833333.33 = tingkat pendapatan per bulan tergolong "Rendah" = skor 1

Berdasarkan hasil wawancara, diperoleh sebesar 71 persen (24 reponden) tergolong dalam kategori tingkat pendapatan rendah. Sedangkan yang tergolong tingkat pendapatan sedang sebesar 20 persen (tujuh responden). Untuk kategori tingkat pendapatan tinggi hanya sebesar 9 persen (tiga responden). Data ini membuktikan bahwa tingkat pendapatan di Kampung Batusuhunan masih tergolong rendah.

\section{Taraf Hidup}

Taraf hidup rumahtangga adalah tingkat kemampuan rumahtangga untuk memenuhi kebutuhan hidupnya. Taraf hidup yang dimaksudkan dalam penelitian ini dapat dilihat dari jenis lantai bangunan tempat tinggal, jenis dinding bangunan tempat tinggal, status kepemilikan rumah, daya listrik, bahan bakar untuk memasak, dan kepemilikan barang berharga.

Untuk jenis pemukiman masyarakat di kampung ini, bangunan sudah permanen dengan lantai keramik dan dinding tembok. Hanya sebagian kecil saja masyarakat yang rumahnya masih tradisional (rumah panggung dengan dinding bilik bambu). Status kepemilikan rumah yang dimiliki adalah milik sendiri, kebanyakan masyarakat membangun rumah di kampung ini karena tanah tersebut warisan dari orang tunya dahulu. Untuk pemakaian daya listrik, masyarakat di Kampung Batusuhunan tergolong unik. Mereka memasang daya listrik satu paket $(900$ watt) untuk digunakan oleh dua rumah sekaligus. Biasanya rumah orangtua yang disambungkan ke rumah anaknya yang sudah berumahtangga.

Masyarakat Batusuhunan masih menggunakan tungku dengan bahan bakar kayu bakar untuk memasak air dan nasi. Namun, seiring dengan masuknya program pemerintah mengenai penggunaan kompor gas, saat ini masyarakat juga sudah memasak menggunakan kompor gas. Untuk keperluan memasak lauk, biasanya masyarakat lebih memilih menggunakan kompor gas karena lebih cepat dan praktis. Kepemilikan barang berharga yang dimaksud dalam penelitian ini adalah mobil, motor, komputer, emas, lemari es, televisi, HP, dan radio. Kemampuan masyarakat membeli barang berharga tersebut bukan karena adanya tambahan dari usaha ekowisata, melainkan karena mereka butuh untuk membelinya. Contohnya saja, responden yang memiliki motor, membutuhkan motor untuk berbelanja persediaan dagangannya yang pergi ke pasar, terkadang motornya pun digunakan untuk ojek motor. Kepemilikan 
komputer juga dibutuhkan untuk keperluan anak-anak yang bersekolah. Untuk pembelian HP, masyarakat membelinya untuk komunikasi dengan keluarga dan teman-teman.

\section{Kondisi Ekonomi Masyarakat Setelah Adanya Ekowisata}

\section{Mata Pencaharian Masyarakat}

Ekowisata telah membuka kesempatan kerja baru kepada masyarakat kampung batusuhunan. Adanya kesempatan kerja baru dapat menambah penghasilan keluarga. Ekowisata mendatangkan wisatawan yang berkunjung ke kampung ini untuk menikmati keindahan alam sehingga masyarakat dapat menangkap peluang kerja karena hadirnya ekowisata. Kampung Batusuhunan menjadi pusat aktivitas wisatawan seperti tidur, makan, dan jalan-jalan. Kesempatan kerja karena adanya ekowisata meliputi: penginapan (homestay), tour guide, katering, menjual kue ringan dan fotografer. Lapangan kerja baru pun semakin luas di bidang ekowisata dan menambah penghasilan masyarakat. Jenis pekerjaan di bidang ekowisata ada yang bersifat utama bagi masyarakat, ada juga sebagai pekerjaan sampingan.

Semenjak ada perencanaan pengembangan ekowisata di Kampung Batusuhunan, terdapat pihak yang ingin membangun villa di kampung ini. Namun rencana tersebut ditolak dan sebagai penggantinya, rumah warga dijadikan tempat menginap para wisatawan. Warga sangat senang apabila wisatawan dapat menginap di rumahnya, mereka pun tidak memastikan harga untuk pembayaran penginapan. Terkadang wisatawan memberikan Rp 50000 hingga Rp 200000 per malam. Untuk pemandu wisata, wisatawan biasa memberikan sebesar Rp 30 000 - Rp 50000 dan adapula wisatawan yang terkadang tidak membayar sama sekali. Permintaan katering untuk makan para wisatawan masih jarang diterima oleh masyarakat, kecuali jika terdapat rombongan wisatawan yang datang dan turis dari luar. Hal ini terjadi karena kebanyakan wisatawan jika berkunjung selalu membawa bekal makanan dari rumah sehingga jarang untuk memesan katering di kampung ini. Kesempatan kerja lain yang terbuka adalah jasa fotografer. Salah satu masyarakat yang hobi fotografi mulai membuka usaha ini semenjak pengembangan ekowisata. Permintaan dari wisatawan pun beragam, mulai dari berfoto dengan kawan-kawan sekolah, keluarga, hingga foto pre-wedding pun dilakukan di kawasan ekowisata Curug Cigangsa.

\section{Tingkat Pendapatan Rumahtangga}

Adanya ekowisata memang menambah penghasilan masyarakat Batusuhunan, namun tidak berpengaruh banyak bagi perekonomian masyarakat setempat. Wisatawan yang datang tidak tentu jumlah dan waktunya. Jumlah wisatawan pada hari libur biasanya meningkat dan pada hari biasa/ kerja ekowisata terlihat sepi pengunjung. Wisatawan yang datang ada yang membuat janji terlebih dahulu dan ada yang langsung datang ke Curug Cigangsa. Wisatawan yang membuat janji biasanya memesan katering dari masyarakat setempat, bahkan ada yang menginap di rumah masyarakat.

Penduduk didalam penelitian ini adalah responden yang bekerja di bidang ekowisata. Rata-rata pendapatan rumahtangga per bulan setelah adanya ekowisata adalah Rp 2250 500, jumlah ini meningkat dari sebelum adanya ekowisata yang rata-rata pendapatan rumah tangga per bulan adalah Rp 1367

Setelah adanya ekowisata, jumlah pendapatan per bulan rumahtangga pun berubah. Pendapatan terendah rumah tangga menjadi Rp 400000 dan untuk pendapatan tertinggi sebesar RP 5250 000. Adanya kedatangan wisatawan ini, menjadikan masyarakat tidak dapat memastikan pendapatan yang diterima. Walaupun demikian, adanya ekowisata tetap dapat meningkatkan pendapatan penduduk. Hal ini dapat dijelaskan pada Tabel 3 .

Tabel 3. Jumlah dan Persentase Perubahan Tingkat Pendapatan Rumahtangga Kampung Batusuhunan

\begin{tabular}{|c|c|c|c|c|c|}
\hline \multirow{2}{*}{$\begin{array}{l}\text { Tingkat } \\
\text { Pendapatan }\end{array}$} & \multirow{2}{*}{$\begin{array}{l}\text { Sebelum } \\
\Sigma(\text { orang) }\end{array}$} & \multicolumn{3}{|c|}{ Sesudah } & \multirow{2}{*}{$\begin{array}{l}\Delta \\
(\%)\end{array}$} \\
\hline & & $\%$ & $\begin{array}{c}\Sigma \\
\text { (orang) }\end{array}$ & $\%$ & \\
\hline Tinggi & 3 & 9 & 7 & 21 & 21 \\
\hline Sedang & 7 & 20 & 12 & 35 & 15 \\
\hline Rendah & 24 & 71 & 15 & 44 & 27 \\
\hline Jumlah & 34 & 100 & 34 & 100 & \\
\hline Rataan Skor & 11.3 & & 11.3 & & \\
\hline
\end{tabular}

$\Delta$ (delta) $=$ Perubahan tingkat pendapatan rumahtangga Kampung Batusuhunan

Tabel 3 memperlihatkan perubahan pendapatan rumahtangga di Kampung Batusuhunan. Berdasarkan tabel 3, Awalnya jumlah responden yang tergolong dalam kategori pendapatan rendah sebesar 71 persen ( 24 responden), dapat disimpulkan bahwa hampir seluruh rumahtangga di kampung ini tergolong kategori tingkat pendapatan rendah. Kemudian setelah adanya ekowisata tingkat pendapatan mengalami perubahan yang signifikan menjadi 44 persen (15 responden). Perubahan persentase responden adalah sebesar 27 persen atau mengalami penurunan dari kondisi sebelum adanya ekowisata, artinya responden yang memiliki tingkat pendapatan tergolong rendah semakin berkurang semenjak adanya ekowisata. Hal ini membuktikan bahwa ekowisata dapat membantu perekonomian masyarakat golongan rendah di Kampung Batusuhunan meningkatkan kualitas hidupnya. Hasil pendapatan yang diterima digunakan oleh masyarakat untuk meningkatkan kualitas hidup baik dalam bidang pendidikan maupun kesehatan mereka.

Pada responden yang tergolong dalam kategori sedang, awalnya jumlah responden yang memiliki tingkat pendapatan sedang sebesar 20 persen (tujuh responden), kemudian mengalami perubahan setelah adanya ekowisata sebesar 35 persen (12 responden). Perubahan persentase responden adalah sebesar 15 persen. Perubahan tingkat pendapatan responden menjadi meningkat karena dipengaruhi oleh adanya ekowisata berbasis masyarakat di Kampung Batusuhunan.

Pada responden yang tergolong dalam kategori tinggi, awalnya jumlah responden yang memiliki tingkat pendapatan tinggi sebesar sembilan persen (tiga responden), kemudian mengalami perubahan setelah adanya ekowisata sebesar 21 persen (tujuh responden). Perubahan persentase responden adalah sebesar 12 persen. Perubahan tingkat pendapatan responden menjadi meningkat karena dipengaruhi oleh adanya ekowisata berbasis masyarakat di Kampung Batusuhunan.

Berdasarkan uji statistik t dengan nilai $\alpha$ sebesar 0.05 , diperoleh nilai signifikansi 0.00 serta nilai thitung 4.044 (Lampiran 
6) lebih besar dari t tabel 2.021. Uji statistik sebesar 0.00 ( $<5$ persen) artinya terdapat beda nyata tingkat pendapatan rumahtangga sebelum adanya ekowisata dan setelah adanya ekowisata di Kampung Batusuhunan.

\section{Taraf Hidup}

Secara keseluruhan, perubahan taraf hidup belum dapat dirasakan oleh masyarakat Batusuhunan setelah adanya ekowisata. Hal ini terjadi karena pengembangan ekowisata baru saja dimulai dan baru berjalan kurang lebih selama tiga tahun, yaitu sejak awal perencanaan pengembangan ekowisata pada tahun hingga saat penelitian ini berlangsung (2013).

Peningkatan pendapatan dari usaha ekowisata digunakan untuk kebutuhan hidup sehari-hari dan keperluan sekolah anak-anak. Sehingga untuk melihat bukti fisik jenis lantai bangunan tempat tinggal, jenis dinding bangunan tempat tinggal, status kepemilikan rumah, dan daya listrik masih tetap sama jika dibandingkan dengan 3 tahun yang lalu. Dengan demikian, dapat disimpulkan bahwa taraf hidup masyarakat Kampung Batusuhunan sebelum dan setelah adanya ekowisata tidak mengalami perubahan karena adanya ekowisata. Untuk lebih jelasnya, dapat dilihat pada tabel 4.

Tabel 4. Jumlah dan Persentase Perubahan Tingkat Taraf Hidup Rumahtangga Kampung Batusuhunan

\begin{tabular}{|c|c|c|c|c|c|}
\hline \multirow{2}{*}{$\begin{array}{l}\text { Tingkat } \\
\text { Pendapatan }\end{array}$} & \multirow{2}{*}{$\begin{array}{l}\text { Sebelum } \\
\Sigma \text { (orang) }\end{array}$} & \multicolumn{3}{|c|}{ Sesudah } & \multirow{2}{*}{$\begin{array}{c}\Delta \\
(\%)\end{array}$} \\
\hline & & $\%$ & $\underset{\text { (orang) }}{\Sigma}$ & $\%$ & \\
\hline Tinggi & 19 & 56 & 20 & 59 & 3 \\
\hline Rendah & 15 & 44 & 14 & 41 & 3 \\
\hline Jumlah & 34 & 100 & 34 & 100 & \\
\hline $\begin{array}{l}\mathrm{R} \text { a } \mathrm{t} \text { a a } \mathrm{n} \\
\text { Skor }\end{array}$ & 16.7 & & 17.0 & & \\
\hline
\end{tabular}

$\Delta$ (delta) $=$ Perubahan tingkat pendapatan rumahtangga Kampung Batusuhunan

Tabel 4 memperlihatkan perubahan taraf hidup rumahtangga di Kampung Batusuhunan. Berdasarkan tabel 4, Awalnya jumlah responden yang tergolong dalam kategori taraf hidup rendah sebesar 44 persen (15 responden), Kemudian setelah adanya ekowisata tingkat pendapatan mengalami perubahan yang menjadi 41 persen (14 responden). Perubahan persentase responden adalah sebesar tiga persen. Hal ini membuktikan bahwa ekowisata tidak mempengaruhi perbuhan taraf hidup rumahtangga masyarakat Batusuhunan karena tingkat perubahan hanya tiga persen. Angka tiga persen tidak dapat mewakili perubahan tingkat taraf hidup masyarakat karena ekowisata baru berjalan selama tiga tahun.

Sama halnya dengan kategori responden bertaraf hidup rendah, pada responden yang tergolong dalam kategori tinggi, awalnya jumlah responden yang memiliki tingkat pendapatan tinggi sebesar 59 persen (20 responden), kemudian mengalami perubahan setelah adanya ekowisata sebesar 41 persen (14 responden). Perubahan persentase responden adalah sebesar 3 persen. Angka tiga persen tidak dapat mewakili perubahan tingkat taraf hidup masyarakat karena ekowisata baru berjalan selama tiga tahun. Sehingga pengukuran taraf hidup dengan indikator jenis lantai bangunan tempat tinggal, jenis dinding bangunan tempat tinggal, status kepemilikan rumah, dan daya listrik masih tetap sama jika dibandingkan dengan 3 tahun yang lalu.

\section{SIMPULAN DAN SARAN}

\section{Simpulan}

Pengembangan ekowisata berbasis masyarakat di Kampung Batusuhunan memberikan perubahan berupa pengaruh yang positif bagi masyarakat batusuhunan khususnya pada aspek ekologi, sosial, dan ekonomi. Pada aspek ekologi, perubahan masyarakat semenjak adanya ekowisata adalah kesadaran untuk menjaga lingkungan dengan cara membuang sampah pada tempat sampah khusus dan mulai melakukan gaya hidup ramah lingkungan.

Pada aspek ekonomi, peluang pekerjaan yang diperoleh dari sektor ekowisata dapat menjadi tambahan penghasilan bagi keluarga. Peningkatan pendapatan digunakan oleh masyarakat untuk kebutuhan hidup sehari-hari dan biaya pendidikan. Namun, perubahan taraf hidup belum dapat dirasakan oleh masyarakat Batusuhunan setelah adanya ekowisata. Hal ini terjadi karena pengembangan ekowisata baru saja dimulai dan baru berjalan kurang lebih selama 3 tahun, yaitu sejak awal perencanaan pengembangan ekowisata pada tahun 2010, hingga saat penelitian ini berlangsung (2013).

\section{Saran}

Berdasarkan hasil penelitian, ekowisata berbasis masyarakat di Kampung Batusuhunan masih perlu diarahkan kepada strategi dan kebijakan pengembangan ekowisata dengan mempertimbangkan potensi ekologi, sosial, dan budaya masyarakat setempat. Pengelolaan ekowisata berbasis masyarakatyang diterapkan saat ini masih dalam struktur yang sederhana. Perlu adanya kerjasama dari pemerintah daerah yang tidak hanya sekedar dana, yaitu kegiatan pemberdayaan masyarakat. Pemberdayaan ini meliputi pelatihan di bidang ekowisata seperti bagaimana mengelola ekowisata, membuat souvenir khas, tatacara menjadi pemandu, ataupun belajar bahasa inggris. Selain itu, perlu dilakukan penelitian secara berkala setiap tahun untuk mendapatkan data yang lebih lengkap dari pelaksanaan ekowisata berbasis masyarakat serta dampak yang ditimbulkan dari kegiatan ekowisata untuk kebijakan dan arahan pengembangan ekowisata selanjutnya.

\section{DAFTAR PUSTAKA}

Abdulsyani. 1994. Sosiologi Skematika, Teori dan Terapan. Jakarta (ID): Bumi Aksara.

Adelia A. 2012. Persepsi Masyarakat terhadap Pengembangan Kawasan Ekowisata Islami Curug Cigangsa [skripsi]. Bogor (ID): Institut Pertanian Bogor.

Ayuningtyas DI. 2012. Dampak Ekowisata terhadap Kondisi Sosio-ekonomi dan Sosio-ekologi Masyarakat di Taman Nasional Gunung Halimun Salak [skripsi]. Bogor (ID): Institut Pertanian Bogor.

Bungin B. 2007. Penelitian Kualitatif: Komunikasi, Ekonomi, Kebijakan Publik, dan Ilmu Sosial Lainnya. Jakarta (ID): Kencana.

Damanik J dan Weber HF. 2006. Perencanaan Ekowisata: dari Teori ke Aplikasi. Yogyakarta 
(ID): Andi.

Fennell, D.A. 1999. Ecotourism an Introduction. London: Routledge.

Hasan I. 2004. Analisis Data Penelitian dengan Statistik. Jakarta (ID): Bumi Aksara.

Rahman A. 2009a. Evaluasi Tanggung Jawab Sosial PT Holcim Indonesia Tbk (Studi Kasus Baitul Maal wa Tamwil Swadaya Pribumi, Kecamatan Klapanunggal, Kabupaten Bogor, Provinsi Jawa Barat) [skripsi]. Bogor [ID]: Institut Pertanian Bogor.

Saputro PB. 2011. Tata Kelola Wisata di Dataran Tinggi Dieng Provinsi Jawa Tengah. [skripsi]. Bogor (ID): Institut Pertanian Bogor.

Sedarmayanti. 2005. Membangun Kebudayaan dan Pariwisata (Bunga Rampai Tulisan Pariwisata). Bandung (ID): Penerbit Mandar Maju.

Singarimbun M dan S Effendi. 1989. Metode Penelitian Survai. Jakarta (ID): LP3ES.

Soekanto S. 1982. Sosiologi Suatu Pengantar. Jakarta (ID): PT RajaGrafindo Persada.

Soemarwoto O. 1989. Analisis Dampak Lingkungan. Yogyakarta (ID): Gajah Mada University Pr.

Tafalas M. 2010. Dampak Pengembangan Ekowisata terhadap Kehidupan Sosial dan Ekonomi Masyarakat lokal studi kasus ekowisata bahari Pulau Mansuar Kabupaten Raja Ampat [tesis]. Bogor (ID): Institut Pertanian Bogor. Tuwo A. 2011. Pengelolaan Ekowisata Pesisir dan Laut. Surabaya (ID): Brilian Internasional.

Untari R. 2009. Strategi Pengembangan Ekowisata Berbasis Masyarakat di Zona Wisata Bogor Barat Kabupaten Bogor [tesis]. Bogor [ID]: Institut Pertanian Bogor.

Warpani S. 2007. Pariwisata dalam Tata Ruang Wilayah. Bandung (ID): Institut Teknologi Bandung

WWF Indonesia. 2009. Prinsip dan Kriteria Ekowisata Berbasis Masyarakat. Jakarta (ID): WWF.

Yoeti OA. 2008. Ekonomi Pariwisata: Introduksi, Informasi, dan Implementasi. Jakarta (ID): Kompas.

Breman J,. 1980. The Informal Sector in Research, Theory and Pactise, Comparative Asian Studies Program Publication No.III. Sektor Informal dalam Urbanisasi, Pengangguran, dan Sektor Informal di Kota. Manning C dan Effendi TN. Jakarta [ID]: PT Gramedia. 138181.

Dharmawan, A.H., 2007. Sistem Penghidupan dan Nafkah Pedesaan: Pandangan Sosiologi Nafkah (Livellihood Sociology) Mazhab Barat dan Mazhab Bogor. [internet]. [Diunduh 11 Maret 2012]. Bogor [ID]: Institut Pertanian Bogor. ISSN: 1987-4333, vol. 01, no. 2. dapat diunduh dari: http://jurnalsodality.ipb.ac.id/ jurnalpdf/edisi2-1.pdf
Ellis, F., 2000. Rural Livehoods and Diversity in Developing Countries. New York: Oxford University Press

Hart, K., 1973. Informal Income Opportunities and Urban Employment in Ghana. Sektor Informal dalam Urbanisasi, Pengangguran, dan Sektor Informal di Kota. Manning C dan Effendi TN. Jakarta[ID]: PT Gramedia. 78-89

Iqbal, M., 2004. Strategi Nafkah Rumahtangga Nelayan (studi kasus di dua desa nelayan tangkap Kabupaten Lamongan Jawa Timur). [Tesis]. Bogor[ID]: Institut Pertanian Bogor. 1-183

Mashithoh, A.D., 2005. Analisis Strategi Nafkah Rumahtangga Petani Perkebunan Rakyat (Suatu Kajian Perbandingan: Komunitas Petani Perkebunan Teh Ciguha Jawa Barat dan Komunitas Petani Perkebunan Tebu Puri Jawa Timur. [skripsi]. Bogor [ID]: Institut Pertanian Bogor. $1-130$

McGee. T.G., 1971. The Urbanization Process in The Third World. Sektor Informal dalam Urbanisasi, Pengangguran, dan Sektor Informal di Kota. Manning C dan Effendi TN. Jakarta[ID]: PT Gramedia. 34-60

Musyarofah, S.A., 2006. Strategi Nafkah Rumahtangga Miskin Perkotaan (Studi Kasus Kampung Sawah, Kelurahan Semper Timur, Kecamatan Cilincing, Jakarta Utara). [skripsi]. Bogor[ID]: Institut Pertanian Bogor. 1-146

Singarimbun, M., Effendi, S. 2008. Metode Penelitian Survei. Jakarta [ID]: LP3ES. 1-336

Sukandar, D., Suhanda, N.S., Amalia, L., Khairunnisa., 2008. Analisis Diskriminasi untuk Menentukan Indikator Garis Kemiskinan. [jurnal]. Bogor[ID]. Institut Pertanian Bogor. 94-100

Suwartika, R., 2003. Struktur Modal Usaha dan Fungsi Modal Sosial dalam Strategi Bertahan Hidup Pekerja Migran di Sektor Informal (Studi Kasus Kecamatan Pelabuhan Ratu dan Kecamatan Cisaat, Kabupaten Sukabumi, Provinsi Jawa Barat). [skripsi]. Bogor[ID]: Institut Pertanian Bogor. 1-127

Tan, S.S., 2006. Strategi Adaptasi Komunitas Lokal Menanggapi Kehadiran Kampus IPB di Darmaga (Studi Kasus Komunitas Desa Babakan, Kecamatan Darmaga, Kabupaten Bogor). [Tesis]. Bogor [ID]: Institut Pertanian Bogor. 1-155

Todaro, M.P, Stilkind J., 1981. City Bias and Rural Neglect: the Dilemma of Urban Development. Sektor Informal dalam Urbanisasi, Pengangguran, dan Sektor Informal di Kota. Manning C dan Effendi TN. Jakarta[ID]: PT Gramedia. 4-31 